\title{
A Qualitative Research on Administration Ethics at School*
}

\author{
Semra Kiranli Güngör ${ }^{1}$, Funda Özkara ${ }^{2}$ \\ ${ }^{1}$ Faculty of Education, Eskişehir Osmangazi University, Eskişehir, Turkey \\ ${ }^{2}$ Eskişehir Directorate of National Education, Eskişehir, Turkey \\ Correspondence: Assistant Prof. Dr., Semra Kiranli Güngör, Faculty of Education. Eskişehir Osmangazi University, \\ Meşelik Kampüsü, 26480 Eskişehir, Turkey.
}

Received: August 20, 2017

doi:10.11114/jets.v5i11.2705
Accepted: October 8, 2017

Online Published: October 15, 2017

URL: https://doi.org/10.11114/jets.v5i11.2705

\begin{abstract}
The aim of the research is to reveal the opinions of the school administrators about the administration ethics. In this study, 30 administrators working in the middle schools of Eskişehir province center in the 2016-2017 academic year were reached. In the study, data were gathered by interview technique which is one of the qualitative research methods. All of the interviews were conducted by the researcher individually. During the interviews, voice recordings were made with the interviewers who consented to this and note-taking system was used with the interviewers who did not consent to voice recording. Data were analyzed by content analysis method. Analyzing the content of the interview, themes and sub-themes were created according to thematic coding. According to the results of the research, the administrators stated that there was no written professional ethical principles in the school and they did not need them. However, there are officially written professional ethical principles. According to school administrators, the source of unethical behavior is inadequacy and being under pressure by many factors. However, some administrators can ignore unethical behavior. School administrators prefer to give punishment to the staff directly who will act unethically. Ethical practices in school administrators' schools are not at the level as it is supposed to be and are not functional. School administrators indicate that there is a professional difference between men and women. It is obvious that school administrators who participated in this study have deficiencies in ethics in school administration.
\end{abstract}

Keywords: school administrators, administrative ethics, qualitative research, interview technique, content analysis, educational administration

\section{Introduction}

The relationships people make in the society are based on ethics. Human relationships are supposed to be as part of right and good behaviours and based on the values such as affection, respect, honesty and trust. Ethics has great importance in the education field in addition to its importance in the social field. Schools that build the future must have ethical values and must be managed by administrators who have ethical values. Educational institutions are the result of the institutionalization of people in order to live together and serve a common purpose. Therefore, the principles organizing the educational institution are derived from basic ethical principles (freedom, equality, justice and human dignity) and aimed at community well-being (Pieper, 2012).

School administrators must be administrators who have ethical perception, who are faithful to ethical principles and focused on ethical decision-making and who avoid unethical behaviors. The actions of the school administrator are often influenced by personal values and personal ethical principles built upon them. It is not always easy to separate professional ethical principles and personal ethical principles (Kiranl1, 2002). If there is code of ethics in the school, it will be easier for the administrators to work in this field. It is essential and crucial for administration ethics that administrators determine and practise ethical principles that will create ethical norms of behaviour in schools, namely code of ethics.

\footnotetext{
"This study is a small part of the Funda Özkara's Eskişehir Osmangazi University, Institute of Educational Sciences, Department of Educational Sciences, Department of Educational Administration Master thesis work that was carried out on May 25, defended and resulted in success with Consultancy of Assistant Prof. Dr. Semra KIRANLI GÜNGÖR.
} 


\subsection{Ethics}

Ethics is a philosophy coming from the Greek word ethos and deals with human behavior, actions and judgements. "Ethos" means habit, tradition, custom. The ethical word is expressed in English as "ethics". Morality in English, which is the meaning of the concept of "ahlak" is derived from the word "moralis" in Latin and corresponds to meanings such as ethics, manners and custom in Turkish (Akarsu, 1982; Pieper, 2012; Kuçuradi, 2011).

Ethics is closely related to morality and moral values. In this context, ethics is the subdivision of philosophy, which is related to morality and moral values (Cevizci, 2008). Ethics is a field that deals with moral behavior, action and judgements. Ethics is a theory that defines right and wrong behavior and forms ethical rules (Akarsu, 1982; Pieper, 2012). In general terms, ethics is a code composed of values and moral rules that lead individual or group to right or wrong behavior. Ethics sets standards for what is good or bad in practice and in decision-making. Ethics concerns the internal values that are part of the organization's culture and provides for the creation of social responsibility decisions related to the external environment (Daft, 2014). Ethics is a field of moral philosophy that goes down to the essence and foundations of morality as a philosophical activity (Aydın, 2006). Ethics is a guide to individual who seeks good and right as a need for a happy life in society. Ethics tries to question and shape the underlying thought of human behavior.

\subsubsection{Types of Ethics and Philosophies}

Studies conducted in the field of ethics today are explained mainly in four groups; descriptive ethics, normative ethics, meta ethics and applied ethics (Pieper, 2012). (1) Descriptive ethics: descriptive ethics which is a consequence of the application of the scientific approach to ethics, deals with sociological and psychological phenomena, or that should occur, in the context of ethics and moral action. It does not declare a norm or rule, but only observes human action and describes the consequences of actions (Cevizci, 2008: 6). (2) Normative ethics: It gives some criterion to the questions like how the action will be, how to live or how to be a person morally, how to be a fair society (Pieper, 2012; Cevizci, 2008:7). (3) Meta ethics: According to meta ethics; "It examines whether the ethical standards, values, principles and theories will be verified or not, the judgements and the concepts that the normative ethics reveals (4) Applied ethics: It deals with the application of ethical dilemmas, choices, standards and moral theories and its concepts which appear in particular circumstances while serving in various professions to a particular subject (Cevizci, 2008: 10).

Educational types of ethics can be grouped into four as justice, value, criticism, professional ethics: 1. Justice ethics: The ethics of justice allows peace in society and belief in the legal system increased. The democratic side of the ethics of justice is to care about the equal sovereignty and freedom of the people 2. Value ethics (Phenomenological understanding): The ethical understanding that cares more about the qualitative content than the formal structure of an ethical action is the ethics of phenomenological value. Qualifying the morality of an action to its form, it attaches importance to the decision which the action confirms can be generalized or can not be generalized in order to become an absolute law 3.Criticism ethics: It includes inequalities and other factors (oppression, inequality, concession, race, gender, disability groups, discrimination) which are mainly class-based and constrain the power and voice of individuals and groups. The general purpose of critical ethics is to correct the mistakes of disseminating basic human rights and to define ethical principles, values while struggling with inequalities. 4. Professional ethics: It can be defined as the rules of behaviour that must be obeyed in the professions related to human beings. (Kiranl1, 2002; Pieper, 2012).People in the same profession all over the world must act in accordance with this code of behaviour.

\subsection{Ethics and Code of Ethics in School Administration}

The most important factor that indicates the importance of the ethics in school management is decision making process. One of the guidelines developed for ethical decision making is according to Kiranlı and Ilgan (2007): In defining the problem, people should ask some questions, (1) Does this situation concern me? (2) Who am I? What should I do? (3) Is this situation about the employees? Is it about the institution? According to Sergiovanni (2015); The task of the school is to overcome "balanced personality and virtue" with the knowledge and skills of the students. To establish these standards, there must be an ethical framework and common sense of the school administrator. Principles of ethical behavior that the administrator should follow; Justice, equality, honesty and integrity, impartiality, responsibility, human rights, humanism, loyalty, superiority of law, love, tolerance, respect, frugality, democracy, positive human relations, openness, rights and freedoms, granting the right of labor, resistance against illegal orders (Aydın, 2001). The actions of the school administrator are influenced by personal values and personal ethical principles. It is not always easy to separate personal code of ethics with professional code of ethics (Kiranl1 2002).

Ethical principles are a general term. Ethical principles in school administration should be considered as administrative professional code of ethics. Code of ethics is a guiding formal definition about what behavior of employees is acceptable. There are three basic functions of professional code of ethics (Güngör-Kiranl1, 2016). As expressed:"Treat others as you would have them treat you." in ethical philosophy,"The golden rule "is vital (Güngör-Kıranlı and Yıldırım, 
2014). Schools are more likely to be unethical due to their responsibilities in society and the likelihood of encountering pressure groups (Sergiovanni, 2015). Types of unethical behavior can be listed as follows: 1. Discrimination, 2. Favoritism, 3. Bribery, 4. Mobbing, 5. Neglect, 6. Exploitation (abuse) 7. Selfishness, 8. Corruption, 9. Violence-Pressure-Aggression, 10. Including Policy in Job Relations, 11. Insult and Blasphemy, 12. Physical and Sexual Harassment, 13. Abuse of Mission and Adultery, 14. Gossip, 15. Debit (Aydın, 2006).

Legal arrangements to improve ethical practices for civil servants and educators in Turkey are important. Prime Ministry has legislated "Regulation on Ethical Code of Conduct for Public Officials and Procedures and Principles of Application" concerns all public officials with teachers. The establishment of an Ethics Committee for Public Officials (Ethics Committee), creating an ethical contract and that every government official must sign this contract has been accepted. Since 2008, "Ethics Day" has been decided to be celebrated on May $25^{\text {th }}$ and "Ethical Week" in the week which the same day takes place every year throughout Turkey (Official Newspaper, 2004, May, 25). Ministry of Education issued a Circular on Professional Ethical Principles for Educators. Professional Ethical Principles for Educators: 1- Principles about students, 2- Principles of education profession, 3- Principles about education, 4Principles about parents, 5-Principles about school administration and society, 6- Principles of school administrators about teachers, students and parents (Official Newspaper, 2015, June, 24).

Acar (2011), Yilmaz (2006), Aydın (2006), Küçükkaraduman (2006), Turhan (2007), Erdoğan (2007) Baloğlu, Karadağ and Doğan (2008), Taneri (2011), Sunar (2011), Mansuroğlu (2012), Gülcan, Gürkan and Çepni (2012), Ertürk (2012), reached the conclusion that the administrators behave in accordance with the ethics. Turgut (2010), Kiranl1 (2002) have reached the result that administrators can behave unethically. In the study of Evgülü (2009), the need for a special index of professional ethical principles came to the conclusion. Garcia, Cartwright, Winston and Borzuchowska (2003) found that ethical leadership programs could improve the ethical leadership skills of school administrators, Brown, and Trevino (2005) found that ethical leadership was related to honesty, trustworthiness, mutual justice, and counseling.

\subsection{The Purpose of the Research}

The aim of the research is to reveal the opinions of the school administrators about the administration ethics. As standards for education and school management in Turkey can not be developed, principles about ethics and the perception of administration ethics in school administration are not developed either. Problem with administrative behavior arises in an institution where the school administrator does not depend on the administration ethics. Administration ethics should include an administration approach based on values and ethical principles. It is an important requirement to know the views of current school administrators about administration understanding. There is need for a strong ethical administration understanding in educational organizations. School administrators must be an example and a guide with their strong ethical administration practices as well as they must be equipped with strong administrative competence and skills.

What is the administration ethics according to the school administrators? "was the problem of this research.

Answers for the following subject-topics in the light of the determined purpose were sought:

1. Presence of written professional ethics principles and the need for it

2. According to school administrators, the source of unethical behavior

3. The attitude of the school administrator to the unethical person

4. Opinions of school administrators about the professional difference between men and women

With this research, it is aimed to contribute to both researchers and field practitioners by revealing the views of school administrators on administration ethics, determining the positive and negative situations and making necessary suggestions. The lack of qualitative research in the literature is noteworthy compared to quantitative research. For this reason, it is desired to contribute to the field by conducting qualitative research. In Turkey, firstly, after the primary school, it was applied in high school and hardly applied in secondary schools. In this study, it is desired to choose secondary schools and make contribution by recognizing the lack in the field.

\section{Method}

\subsection{The Method of the Research}

Qualitative research method was used in this study. Qualitative research is a preferred technique for systematically examining the meanings inferred from the experiences of people who are being researched or those who are planned to be researched (Ekiz, 2003). Qualitative research is primarily concerned with deeply understanding the phenomenon in its natural environment. Denzin and Lincoln (2005) define qualitative research as a situational activity that explores the place of the observer in the world. Qualitative research is a set of interpreting, material practices that make the world visible. The characteristic of this definition is that it emphasizes the importance of the content or the environment of the 
study being studied. One characteristic of qualitative research is that they are explorative. Exploratory research is very practical and useful in illuminating less studied topics (Neuman and Robson, 2012: 28). Qualitative research method was used in this study. In this research using qualitative research method, case study design was used. Interview is a very good way of accessing people's perceptions, meanings, definitions of situations and constructions of reality (Punch, 2005). For this reason in our study, we preferred interview technique. The aim of the interview is to understand the people's viewpoints, feelings, experiences, thoughts, expectations, aims, perceptions and evaluations. Moreover, there are more quantitative studies than qualitative studies about administrative ethics at school in Turkey. In our study, a general coding was first made with interview data. Categorization was used to make content analysis. Then grouped into themes and sub-themes. Agreement percentage was used. In addition, under the theme and sub-themes, there is a striking citation from the views of the interviewers.

In this research using qualitative research method, case study design was used. The phenomenological approach supports that we should know his/her own perception and experience in order to understand the behavior of the individual. The data were analyzed by content analysis method. The first stage of content analysis can also be called "categorical analysis". This analysis provides the classification of the main substances and the determination of their frequencies. Categorization refers to grouping items that constitute a whole by differentiating them according to certain criteria (Bilgin, 2014). In this study, a general coding was first made with interview data and then grouped into themes and sub-themes. In addition under the theme and sub-themes there is a striking citation from the views of the interviewers.

\subsection{Limitations of the Research}

The scope of the study is limited to 2016-2017 academic year. The study is limited to the views of the administrators participating in the interview. Research is limited to the interview method. Research is limited to the content analysis method.

\subsection{Participants}

The interview was conducted with 30 secondary school administrators. The information about the people is as gender, age, seniority and branch: the administrators consist of 30; 5 women and 25 men. Ages of interviewers; Two people between 25-30 years, three people between 30-35 years, eight people between 35-40 years, six people between 40-45 years, eleven people between $45-50$ years. The seniority of interviewed administrators varies. According to teaching seniority, there are seventeen people between 1-10 years, and thirteen people between 11-20 years. According to the administrational seniority, there are eighteen people between 1-10 years, eight people between 11-20 years, two people between 21-30 years, and there are two people for 30 years and more. Branches; Turkish, Mathematics, Science and technology, Social studies, English, Technology design, Religion.

\subsection{Data Collection}

In this study, data were collected according to interview method from qualitative research methods. The purpose of a structured interview is to identify the parallels and differences between the information that the interviewed individuals give and to make comparisons accordingly (Brannigan, 1985). In this research, a preliminary examination was made before the pilot application, and a draft list was prepared by searching the related literature. Subsequently, questions were prepared and applied for pilot practice, interview form was prepared for the actual interview application by carrying out pilot analysis and evaluations, determining repetitive and unnecessary questions and finalizing the interview form. Appropriate days and hours were determined with the administrators who agreed to participate in the survey and interviews were carried out. All of the interviews were conducted by the researcher individually. interviewers were asked questions in a mutual communication, were encouraged to give detailed and in-depth information, and feedback was made. The purpose of the research was stated and a photocopy of the research permission document and the interview questions were shown to the participants by explaining the ethics subjects that the data of this interviewer would be used only for research, the name of the person who interviewed, the name of the school would be hidden. Voice recordings were made with the people who gave permission in the interviews, and note-taking technique was used with those who did not.

\subsection{Data Analysis}

After the completion of the interviews, the written data was created by using the obtained notes. These written texts were later reviewed. Names of the administrators were not mentioned in interviews. Coding is done as W1, W2 ... for female administrators and $\mathrm{M}, \mathrm{M} 2, \ldots$ for male administrators.

The data were analyzed by content analysis method. The phenomenological approach supports that we should know his/her own perception and experience in order to understand the behaviour of the individual. The data were analysed by content analysis method. The first stage of content analysis can also be called "categorical analysis". This analysis 
provides the classification of the main substances and the determination of their frequencies. Categorization refers to grouping items that constitute a whole by differentiating them according to certain criteria (Bilgin, 2014). In this study, content analysis was done by coding according to the concepts that were inferred. In the survey, a coding process was performed according to participants who gave the same or similar responses to the same questions. Coding for each question has been performed. Participants' responses to each question were tabulated separately. Thus, all participants' responses to a question were examined on the same tab. In addition, the answers given by the participants were coded into tables. Because of encoding the incoming questions, inductive analysis was used to examine the basic characteristics of collected data.

Agreement percentage is checked for the reliability of the work Miles and Huberman (1994, p. 64), the Agreement percentage, was used to calculate the percentage of agreement. $\mathrm{P}=(\mathrm{Nax} 100)(\mathrm{Na}+\mathrm{Nd})(\mathrm{P}:$ Agreement percentage, Na: agreement amount, Nd: disagreement amount). Agreement percentage of the questions included in the interview-encoding key: Question 1 85\%, Question 2 90\%, Question $395 \%$, Question 4 was calculated as 90\% in this research. Average agreement percentage is $\% 90$ and it is reliable.

Mayring (2000) used the expression "reliability of measurement is describing the correctness of the approach." for reliability. It is important to make detailed explanations about data collection and analysis methods. Internal reliability refers to the fact that more than one researcher in the same time measures a phenomenon or event in the same way. This is why more than one researcher should be able to analyze and compare data (Kirk ve Miller, 1986). In this study, researcher and supervisor coded the data separately, a third encoder checked them, and the average of the analyzes of the encoders was taken. All of these studies are the internal reliability indicator of the study. The most important measure to increase the external reliability is the clear definition of the methods and stages. In addition, maximum level of reliable data must be collected. Together with these, the methodological issues and steps of analysis should be clearly stated (Yıldırım and Şimşek, 2013). In this sense, the interview records of the researcher are defined in a comprehensive and detailed manner.

\section{Findings}

The findings of the opinions of the school administrators on the sub-aims to determine their views on the administration ethics were presented in tabular form orderly.

Table 3.1. Presence of written professional ethics principles and the need for it

\begin{tabular}{|c|c|c|c|c|c|}
\hline & MALE & TOTAL & FEMALE & TOTAL & GT \\
\hline \multicolumn{6}{|l|}{ A)Negative } \\
\hline A1)Not in writing & $\begin{array}{l}\text { M1,M 2,M3,M4,M5,M6, } \\
\text { M7,M8,M9,M10,M11, } \\
\text { M12,M13,M14,M15, } \\
\text { M16,M17,M18,M19,M20, } \\
\text { M21,M22,M23,M24,M25 }\end{array}$ & 25 & $\mathrm{~W} 1, \mathrm{~W} 2, \mathrm{~W} 3$ & 3 & 28 \\
\hline A2)I do not need & $\begin{array}{l}\text { M2,M4,M5,M8,M10,M11, } \\
\text { M12,M13,M15,M16,M17, } \\
\text { M20,M21,M22,M23, M25 }\end{array}$ & 17 & W3 & 1 & 18 \\
\hline \multicolumn{6}{|l|}{ B)Positive } \\
\hline $\begin{array}{l}\text { B1) It would be } \\
\text { better }\end{array}$ & $\begin{array}{l}\text { M1,M6,M7,M14,M18, } \\
\text { M19,M24 }\end{array}$ & 7 & W2 & 1 & 8 \\
\hline $\begin{array}{l}\text { B2) There is an } \\
\text { ethical contract }\end{array}$ & M3,M10 & 2 & W1 & 1 & 3 \\
\hline $\begin{array}{l}\text { B3) There is written } \\
\text { in school }\end{array}$ & & & W4,W5 & 2 & 2 \\
\hline Total & & 51 & & 8 & 59 \\
\hline
\end{tabular}

Table 3.1 shows the presence of the professional ethics principles written in the school and the need for it. The themes were collected in two sub-groups as negative and positive.

Examples of opinions on the theme of lack of written professional ethics principles are:

"No. I did not need it. I am trying to spread the principles I have spoken orally. It is already in total quality. "(M5),

"No. I did not need it. Our teachers were informed about this. There is a contract. Teachers know what to do in this subject. "(M10),

"No. We did not need it. There is no behaviour against it among our friends." (M17)

We can say that the administrators who participated in this study do not consider the existing ethical contract as written 
professional ethical principles. It is also evident that administrators do not accept the ethical contract as a written professional ethical principle, they have moved away from the formalities they have done.

Examples of opinions on the theme of I do not need written professional ethical principles:

"No. I did not need it. I am already very close with my staff. I make jokes with the personnel. If my teacher has a problem, I will deal with him/her. I try to get rid of their troubles. I try to win the person who is the opposite of the idea. "(M2),

"No. We did not need it. We are opposed to this in the sense of paperwork. Communication between the administration and the teacher may be interrupted. "(M8),

"No. We do not need it, but if necessary we communicate it individually."(M11)

The eighteen school administrators who participated in this study express they do not need written professional ethical principles in the school shows they do not see them as professional code of ethics and they do not need them.

The following are examples of views on the theme of it would be better if there were written professional ethical principles:

"No. It could be. It can be done. "(M1),

"No. We actually need it. It must be special to the school. "(M7),

"No. We need it. It is necessary. "(M18)

The administrators who participated in this study have the opinion that written professional ethical principles would be good. They are not aware of the ethical contract already existing in the school and they need written professional ethical principles.

Examples from the views on the already existing ethical contract are as follows:

"No. There is a contract. Teachers can react to us by saying that they already know those rules. We did not need it. It can disrupt the family environment. We give examples and apply them."(M3),

"No. I did not need it. Our teachers were informed about this. There is a contract. Teachers know what to do in this subject. "(M10)

The administrators who participated in this study have already signed an ethical contract, there are written ethical principles in the school. These administrators are conscious about the existence and importance of the ethical contract.

Some of the views on the theme of having written professional ethical principles are:

"There are written professional ethical principles. There is a need boundary. However, there is a problem in practice. It is important to internalize these principles. The school has 1800 students and

110 teachers, it is a very crowded school with dual teaching, so there is no sense of class, and there is a morning-afternoon conflict among students."(M1)

"We needed it because the mail came from Ministry of Education."(W4)

Two school administrators have stated that they have written ethical principles in school. There are written professional ethical principles in the school apart from the ethical contract, shows the importance given to this situation.

Table 3.2. According to school administrators, the source of unethical behavior

\begin{tabular}{|c|c|c|c|c|c|}
\hline & MALE & TOTAL & FEMALE & TOTAL & GT \\
\hline A)There is problem & $\begin{array}{l}\text { M1,M2,M3,M4,M5,M7, } \\
\text { M8,M9,M10,M1, } \\
\text { M12,M13,M14,M15, } \\
\text { M16,M17,M19,M20, } \\
\text { M21,M22,M25 }\end{array}$ & 21 & $\begin{array}{l}\text { W1,W2,W3, } \\
\text { W5 }\end{array}$ & 4 & 25 \\
\hline A1)Pressure & $\begin{array}{l}\text { M1,M5,M8,M9,M10,M11,M12,M13,M15, } \\
\text { M16,M17,M21 }\end{array}$ & 12 & $\mathrm{~W} 1, \mathrm{~W} 3, \mathrm{~W} 5$ & 3 & 15 \\
\hline A2)Inadequacy & M2,M3,M4,M7,M14,M19,M20,M22,M25 & 9 & W2 & 1 & 10 \\
\hline $\begin{array}{l}\text { B)There is no problem } \\
\text { Total }\end{array}$ & M6,M18,M23,M24 & $\begin{array}{c}4 \\
46\end{array}$ & W4 & $\begin{array}{l}1 \\
9\end{array}$ & $\begin{array}{c}5 \\
55\end{array}$ \\
\hline
\end{tabular}

Table 3.2 shows the source of unethical behavior. There are two main themes: There is problem about unethical behavior and there is no problem about unethical behavior. The sub-themes related to the theme of problem can be listed as pressure, inadequacy. 
Some of the views on the pressure are:

"I do not think we set an example for the staff. For example, we broke a teacher's heart. If we are not aware of it, we can not make it up. We are breaking ethical rules to protect our position. We have job concern, fear of being excluded from society. "(M8),

"It is certain. There is no difference between those who do good work and those who do not. It is originated from regulations. I see this, but I can not do anything. We have a lot of responsibility but no authority. "(M12)

"When I get into politics, I can not be free. There is responsibility but no authority. "(W1)

The majority of the administrators who participated in this study are aware of the unethical behavior and the cause of this unethical behavior is the pressure.

Below are examples of views on the theme of inadequacy:

"There is a lack of experience in this position because I am new, and I can not be fully ethical in some behaviors." (M14),

"Sometimes happens. I may have been unethical as a human being. In this case, the attitude of the other person is important. "(M2O),

"I do not have problems. However, of course we have shortcomings. It would be best if we had an education in this field. "(W2)

Most of the administrators who participated in the study see that the unethical behavior is present and that the source of this unethical behavior is inadequacy. The fact that school administrators are aware of their own inadequacies as a self-criticism can be a positive step for them.

Below are examples of opinions on the theme of no problem:

"No, I do not like stopping. I always want to be useful. I have never had a problem. I am trying to practice ethical behavior. "(M6),

"I am trying to be ethical in my own way. There are no situations I feel insecure. "(M23)

The five of the school administrators who participated in the study stated that there is no problem about unethical behavior and actually ignore the problems.

Table 3. 3. The attitude of the school administrator to the unethical person

\begin{tabular}{llcccc}
\hline & MALE & TOTAL & FEMALE & TOTAL & GT \\
\hline A)Punishment & M1,M3,M4,M5,M6,M7,M8, & 18 & W2,W3, & 4 & 22 \\
& M9,M11,M12,M13, M17,M18, & & W4,W5 & & \\
& M20,M21,M23,M24,M25 & & & & \\
B) Verbal warning & M5,M6,M8,M9,M11,M24 & 6 & W1,W2,W4 & 3 & 9 \\
$\begin{array}{l}\text { C)Trying to understand } \\
\text { Total }\end{array}$ & M2,M10,M19 & 3 & & & 3 \\
\hline
\end{tabular}

Table 3.3 shows the attitude of the school administrator towards the unethical staff. The themes can be categorized as punishment, verbal warning, trying to understand.

Examples of views on punishment towards unethical personnel include:

"I say it is wrong. If he/she does not change this behavior, I can do formal action. "(M13)

"There is not much to do. However, I try to apply to official ways. "(M17),

"There is need to go to inspection board and to do required things. The punishment is given. "(M23)

Twenty-two administrators who participated in this study expressed that they could directly punish instead of trying to warn or understand the attitude about unethical behavior.

Below are examples of views on the verbal warning about unethical personnel:

"Firstly I talk and warn." (M8),

"I warn verbally. If he/she continues, I warn with an official warning."(M24),

"I behave affectedly. I have nothing else to do. I reveal with my behaviours if I do not like something. After a warning, I give people a chance to think. "(WI)

Ten school administrators who participated in this study would act constructively in a meaningful sense, instead of 
direct punishment against the person who would act unethically.

Examples from the views on the theme of trying to understand against a person who would act unethically are:

"It sometimes can happen. I talk alone in my office. I tell the right one. They usually loose and apologize. I want the person who made the mistake to apologize to the other person and compensate. I leave the heroism to the teacher. "(M2),

"I want to know whether he/she is aware of that or not. I tell him/her not to do if he/she is unconscious. If he/she is conscious, I want him/her to compensate for it. I do legal action if he /she does not compensate for it. "(M19)

Three school administrators who participated in this study would act as a way of trying to understand the unethical person. This rate is very small. In the vast majority, the administrators see the requirement of imposing direct punishment, while others say they would give verbal warning.

Table 3.4. Opinions of school administrators about the professional difference between men and women

\begin{tabular}{|c|c|c|c|c|c|}
\hline & MALE & $\begin{array}{l}\text { TOTA } \\
\mathrm{L}\end{array}$ & FEMALE & $\begin{array}{l}\text { TOTA } \\
\mathrm{L}\end{array}$ & $\begin{array}{l}\mathrm{G} \\
\mathrm{T}\end{array}$ \\
\hline $\begin{array}{l}\text { A) There is } \\
\text { difference }\end{array}$ & $\begin{array}{l}\text { M2,M3,M5,M7,M8,M9,M11,M13,M15,M16,M17,M19,M20, } \\
\text { M21,M23,M24,M25 }\end{array}$ & 17 & $\begin{array}{l}\text { W1,W2,W3,W4, } \\
\text { W5 }\end{array}$ & 5 & 22 \\
\hline $\begin{array}{l}\text { A1)Female } \\
\text { negative }\end{array}$ & M1,M2,M3,M9,M11,M13,M17,M20,M25 & 9 & $\mathrm{~W} 1, \mathrm{~W} 2$ & 2 & 11 \\
\hline A2)Female positive & M7,M8,M15,M16,M19,M23,M24 & 7 & & & 7 \\
\hline $\begin{array}{l}\text { A3)Male positive } \\
\text { A4)Male negative }\end{array}$ & M2 & 1 & & & 1 \\
\hline $\begin{array}{l}\text { B)There is no } \\
\text { difference }\end{array}$ & $\begin{array}{l}\text { M1,M4,M6,M10, } \\
\text { M12,M14,M18,M22 }\end{array}$ & 8 & & & 8 \\
\hline $\begin{array}{l}\text { C)It depends } \\
\text { Total }\end{array}$ & M5,M21 & $\begin{array}{c}2 \\
44\end{array}$ & W3,W4 & $\begin{array}{l}2 \\
9\end{array}$ & $\begin{array}{c}4 \\
53\end{array}$ \\
\hline
\end{tabular}

Table 3.4 shows the opinions of school administrators on the professional difference between men and women. The themes are there is difference, there is no difference, it depends on the situation. There are four sub-themes as female positive, female negative, male positive, male negative.

Examples of views on the theme of professional difference between men and women include:

"Women are more likely to do this job in a professional sense. They approach children with maternal sentiment and tend to solve problems better. Men are good in the professional sense, but they can not embrace children. "(M8)

"Of course there is difference. Women have pregnancy or other conditions. They get reports. Children can be victims. There is no difference except it. "(M25),

"There is difference. Women make gossip. They use children, preparing meals, their husbands, etc., as an excuse. They are using this situation. "(W5)

Twenty-two of the administrators who participated in this study think that there is a difference between men and women.

Examples from the views on women negative sub-theme are:

"Women are so gossipy. Women are created weak. They are more likely to be tense with each other. We work more easily with men. We talk more freely. "(M2)

"Of course there is difference. We make positive discrimination to female teachers. We are tolerant to them on turns, lessons. Being a mother, having many responsibilities, being emotional make a difference. However, sometimes we are obliged to women where male teachers are not enough. Women are more sensitive, more reactive. There are problems between them. We are trying to reconcile. "(M9),

"Absolutely there is difference. Human is the worm of the human. The woman is the worm of the woman. Personal whims, gossip come into prominence. Women make excuses. It is easier to work with men. Women cannot leave their troubles and go to classes. Men are doing the assigned tasks better. "(W1)

Eleven administrators, who participated in this study, think that there is a professional difference between men and women. They have negative attitudes towards women in a sense that women differ from men in this difference negatively. 
Examples from the views on women positive subtheme are as follows:

"Women are more maternal, they own the children more. In males, there is a fatigue and a sickness over the years. "(M19),

"Female teachers are more tolerant to students, many of them are mothers. They behave more emotionally. "(M23),

"Women are more rigorous. In some jobs, women work more. "(M24)

Seven of the administrators who think that there is a professional difference between men and women express positive attitudes of women compared to men, and they are in a positive attitude towards women in a sense.

Here is the opinion on male positive subtheme:

"We work easier with men. We talk more freely. "(M2)

The following are examples of views on the theme of no professional difference between men and women:

"Depends on personality. Man or woman, both of them are the same if they have desire for working. It

is about people loving their own business. It is about his/her own morality. For example, during a snow holiday, a female teacher walked on the sidewalk. "(M4)

"I do not think there is a difference."(M12)

Eight school administrators who participated in this study have stated that there is no professional difference between men and women. The administrators who express this are aware that there can not be any professional differences between men and women and that if a difference arises, it may originate not from gender but from personal reasons.

Some of the views on the theme of professional difference depends are as follows:

"Of course. The women are very kind, touchy. Men are a bit rude. Female teachers are better at students but relations with men are easier. We can not understand what female teachers are offended. "(M5)

"The woman's professional tendency is different. It actually depends on the individual. "(W3),

"Women have birth, pregnancy, milk permission, a disadvantage of having small children. On the one hand, they have the advantages of predisposing to a job because of their maturity. "(W4)

Four school administrators who participated in this study say that professional differences between the men and the women will change according to the personalities of the teachers, their own developments, and their professional inclination.

\section{Discussion and Conclusion}

In the question of the presence of the professional ethics principles written in the school and the need for it, the majority of the administrators who participated in this study stated that they did not give importance to the ethical contract in writing, and they did not need it. Administrators who participated in this study state that there is not written professional ethics principles in school, I do not need it, it would be better if there were, there is an ethical contract, they have written professional ethics principles in school. Even if few administrators who participated in this study say that it would be better if there were, they are not even aware of the presence of the ethical contract. The number of administrators saying that there are legal ethical contract and written professional ethical principles in the school is very few. In the research of Evgülü (2009) the answers to the question of what kind of studies Ministry of Education was undertaking in order to promote ethical principles reached the conclusion that they only publish circulars and regulations, but they do not practice them. The findings of Evgülü support our finding.Turgut (2010) 's research has found that there is no study for deteregining code of ethics for organizations, education administrators and so there is no code of ethics for them. The findings of Turgut support our findings. According to the findings of Örselli (2010)'s research, more than half of the participants stated that written ethics rules exist in the institution they work in and less of the participants state that there is not written ethics rules, little amount of the respondents state that I do not know and few of them answered as I have no idea. This result does not support the research result. There is an ethical contract that each employee accepts, which should be regarded as written professional ethics principles in the school. The fact that administrators do not regard this ethical contract as a study just on paper and that they are in a behavior that emphasizes the importance of each item in this contract should be considered as one of the priority tasks.

When asked about the source of unethical behavior according to the school administrators who participated in this study, the administrators often gave the opinion that there was a problem (pressure and inadequacy). The administrators who participated in this study ignore the problem, saying that there are few problems, but when asked about the source 
of unethical behavior, it was seen that there were unethical situations and situations that caused these situations to emerge. It is obvious that the administrators who participated in this study are acting unethically by pressing the others, ignoring, and covering the inadequacies, or by ignoring the problem by saying there are no problems. O'Connor and Morrison (2001) emphasized in their study that political behaviors in organizations play an essential role in the formation of unethical behaviors. In another study, Zahra (1985) and Örselli (2010) emphasized the influence of political behavior on the emergence of unethical behavior within the organization. The source of unethical behavior is of great importance in terms of finding the root of the problem. Some administrators ignore the problem in this sense, leading to more problems than solutions. It is essential for the administrator to find out where and how the unethical behaviours are originating by taking self-criticism when necessary and taking precautions related to it, which should be his priority behavior in an ethical environment.

When the school administrator who participated in this study was asked about the attitude towards the unethical staff, the administrators stated opinions as punishment, verbal warning and trying to understand. Administrators who participated in this study mostly stated that they would give punishment. There are also administrators who say firstly verbal warning, then punishment. The rate of those who say trying to understand is very low. Administrators think that they can show a strong attitude towards the staff who act unethically. In Turgut (2010) 's research, the responses of union and association administrators about what their attitudes would be if there was a teacher who acted unethically from their organization; The five administrators said disciplinary committees would be active, an organization said that they would call his/her resignation, and an organization said that the ethics committee processes would start. This result is similar to this finding of the research. The way administrators react in which the staff acts unethically is very different from the way administrators react in which they act unethically. Administrators are insensitive at the point of behaving others in the way that he/she wants others to behave towards his/her own, which is called as golden rule.

When school administrators who participated in this study are asked about their views on the professional difference between men and women, administrators have different opinions (female positive, female negative, male positive, male negative), no differences, and it depends on the situation. It is noteworthy that there is no negative opinion about men as the majority of the administrators are in discriminatory opinions of gender, especially regarding the negative opinions against women. Although it is thought that the low proportion of women in the interviewed group may cause this, female interviewers also have negative opinions about the woman. This is the "queen bee syndrome" in the literature, which shows women's discrimination against women. It supports negative opinions about women in social structure. According to Can (2010) 's study, according to the teachers and administrators working in National Education in Turkey, the gender factor in administration is not significant and the administrator is not regarded as a man or a woman. What is important for education staff is the administration behaviors expected to be shown. At the beginning of these are attitudes of being understanding, being objective and fair, attaching importance to human relations and participation, visioner administration and sharing ideas with others. This result does not support the finding. In the study of Çelikten and Yeni (2004), it was aimed to examine the male and female administrator of educational organizations in terms of administrational and leadership behaviors. Findings related to the gender factor in administration show that the teachers working in the primary education institutions pay more attention to the administrational behaviors expected of them than the genders of the administrator. Among the administration behaviors of male and female teachers' state, there are expectations such as being fair, understanding and giving importance to human relations. These are indications that administrators should carry ethical and humanistic competences as well as technical competences. These findings are not consistent with the finding of difference between men and women. Administrators who participated in this study are expected to stay equally distant to all employees, regardless of whether they are male or female, when considered as a professional. Therefore, they need to be in a more professional manner, away from the prejudices that arise in this field.

Because of knowledge obtained from literature some suggestions can be listed according to this study's results. Administrators who participated in this study ignore the problem in unethical situations. It is necessary to change this behavior of administrators and they should be more sensitive to unethical situations. It is seen that the first behavior of the administrators about the unethical behaviors is punishment. However, the first thing to do is to show the behaviors such as understanding the cause, warning if necessary, and finally giving the punishment. The administrators who participated in this study should develop themselves to act in accordance with the golden rule and develop empathy. The administrators who participated in this study seem to have opinions against women teachers. They need to be conscious of not making gender discrimination. The administrators who participated in this study have expressed difficulty in professions because of being under pressure. They have to behave unethically. Being under pressure related to this issue should be reduced by top authorities and administrators should try to avoid or prevent unethical behavior due to pressure. The centralist hierarchical structure and autocratic understanding in Turkey need to be reduced in management. New researches can be designed in different groups in different research methods. New researches about administrations ethics at school searched, different administrative ethical topics should be find. 


\section{References}

Acar, G. (2011). The relationship between the ethical leadership behaviors by school managers and the organizational justice and motivation levels of physical education teachers (Unpublished Doctorate Thesis). University of Gazi, Ankara, Turkey.

Akarsu, B. (1982). Moral Teachings. İstanbul: Remzi Publisher

Aydın, İ. (2006). Ethics in education and training. Ankara: Pegem A Publishing.

Aydın, İ. P. (2001). Managerial, Professional and Organizational Ethics. Ankara: Pegem A Publishing.

Baloğlu, N., Karadağ, E., \& Doğan, A. E. (2008). Ethical Behaviors among Primary School Administrators. Turkish Journal of Business Ethics. 1(2), 7-26. Retrieved from

http://isahlakidergisi.com/wp-content/uploads/2014/04/sayi02-baloglu.pdf

Bilgin, N. (2014). Content Analysis in SocialSciences. Ankara: Siyasal Publishing.

Brannigan, G. G. (1985).The research interview. Effective Interviewing, Springfield, IL: Charles C. Thomas Publication.

Brown, M. E., \& Treviño, L. K. (2006). Ethical leadership: A review and future directions. The leadership quarterly, 17(6), 595-616. https://doi.org/10.1016/j.leaqua.2006.10.004

Can, N. (2010). School administrators' views on gender in management. Education and Science, 33(147), 35-41. Retrieved from http://egitimvebilim.ted.org.tr/index.php/EB/article/view/685/135

Çelikten, M., \& Yeni, Y. (2004). Evaluation of leader ship and managerial qualities of school principals by cender. Kastamonu Education Journal, 12(2), 305-314.

Cevizci, A. (2008). Introduction to ethics. İstanbul: Paradigma Publications.

Daft, R. L. (2014). The leadership experience. (Sixth Publication). U.S.A.: South-Western CollMe Publication.

Denzin, N. K., \& Lincoln, Y. S. (1994). Handbook of qualitative research. CA, USA, Sage Publication.

Ekiz, D. (2003). Introduction to research methods and methods in education: Qualitative, quantitative and critical theory methodologies. Ankara: An1 Publishing.

Erdoğan, Ç. (2007). Ethical behaviors of primary school administrators. (Unpublished Master Thesis). University of Yildiz Teknik, Istanbul, Turkey.

Ertürk, H. (2012) A research on the ethical leadership level of school principals (Uşak city sample) (Unpublished Master's Thesis) University of Uşak, Uşak, Türkiye.

Evgülü, S. İ. (2009). Comparison of the Ethical Principles Applicable to Elementary School Administrators in the European Union Countriesand in Turkey. (Unpublished Master's Thesis). University of Gaziantep, Gaziantep, Turkey.

Garcia, J. G., Cartwright, B., Winston, S. M., \& Borzuchowska, B. (2003). A transcultural integrative model for ethical decision making in counseling. Journal of Counseling and Development, 81(3), 268-277. https://doi.org/10.1002/j.1556-6678.2003.tb00253.x

Gülcan, M, G., Gürkan, K. A. Ç., \& Çepni, O. (2012). Examınıng prımary school prıncıpals' ethıcal leadershıp behaviours according to different variables. The Journal of Turkish Educational Sciences Winter, 10(1), 139. Retrieved from http://www.tebd.gazi.edu.tr/index.php/tebd/article/view/102/89

Güngör-Kıranlı, S., \&Yıldırım, Y. (2014). Views of Information Technologies Guide Teachers With Regard to Computer Ethics. Journal of Computer and Education Research, 2(4). 23-50. Retrieved from http://dergipark.ulakbim.gov.tr/jcer/article/view/5000046182/5000074425

Güngör-Kıranl1, S. (2016). The Prediction Power of Servant and Ethical Leadership Behaviors of Administrators on Teachers' Job Satisfaction. Retrieved from http://www.hrpub.org/download/20160430/UJER31-19506366.pdf Universal Journal of Educational Research, 4(5), 1180-1188.

Kıranl1, S. (2002). Qualification of Secondary School Administrators to Apply Ethical Principles and to Resolve Ethical Principles. (Unpublished Master Thesis). Osmangazi Üniversitesi, Eskişehir, Turkey.

Kıranl, S., \& Ilgan, A. (2007). Ethics In The Process Of Decision Making In Educational Organizations. University of Mehmet Akif Ersoy, Journal of Education Faculty, 8(14), 150-164

Kirk, J., \& Miller, M. L. (1986). Reliability and validity in qualitative research. USA. CA. Sage Publication. https://doi.org/10.4135/9781412985659 
Küçükkaraduman, E. (2006). Research of ethical behaviours of primary school managers (Unpublished Master's Thesis), University of Gazi, Ankara, Turkey.

Kuçuradi, İ. (2011). Ethics. Ankara: Turkey Philosophy Institution Publication.

Mansuroğlu, Ç, D. (2012). Investigation of the relationship between primary school principals' ethical behavior and school climate. (Unpublished Master's Thesis). University of Yeditepe, İstanbul, Türkiye.

Mayring, P. (2000). Qualitative content analysis. Forum: Qualitative Social Research, 1(2). 93-115. Retrieved from http://www.qualitative-research.net/fqs-texte/2-00/02-00mayring-e.html

Miles, M. B., \& Huberman, A. M. (1994). An expanded source book qualitative data analysis.(Second Edition). California: Sage Publications

Neuman, W. L., \& Robson, K. (2012). Basics of social research: Qualitative and quantitative approaches. USA, Wisconsin. Pearson Publishing.

O'connor, W. E., \& Morrison, T. G. (2001).A comparison of situational and dispositional predictors of perceptions of organizational politics. The Journal of Psychology, 135(3), 301-312. https://doi.org/10.1080/00223980109603700

Official Newspaper (2004, May, 25). Ethics Day and Ethical Week. Retrieved from “ http://etik.meb.gov.tr/mevzuat_genelge.pdf

Official Newspaper (2015, June, 24). Ethical principles for educational service providers. Retrieved from http://erenler.meb.gov.tr/meb_iys_dosyalar/2015_07/07044450_meslekkietik.pdf .

Örselli, E. (2010). Social and administrative ethical values and dilemmas in Turkey: An applied research. (Unpublished Doctorate Thesis). University of Selçuk, Konya, Turkey.

Pieper, A. (2012). Introduction to ethics. İstanbul: Ayrıntı Publication.

Punch, K. F. (2014). Introduction to Social Research: Quantitative and Qualitative Approaches. (Third edition). U.S.A.Sage Publication.

Sergiovanni, T. (2015). Moral Leadership: Getting to the heart of school improvement. (S. Kıranlı- Güngör, Translation.) Ankara: Nobel Publication.

Sunar, Ö, B. (2011).The school managers' ethical behaviours. (Unpublished Master's Thesis), University of Y1ldız Teknik, İstanbul, Türkiye.

Taneri, A. (2011). The relationship between ethical leadership and organizational health in primary schools. (Unpublished Master's Thesis), University of Gazi, Ankara, Turkey.

Turgut, N. (2010). The approach of vocational associations towards the problem of vocational ethics of administrators and teachers working in public elementary schools. (A qualitative research). (Unpublished Master's Thesis).University of Yeditepe, İstanbul. Turkey.

Turhan, M. (2007). The effect of ethical leadership behaviors of high school and vocational high school principals on social justice in schools. (Unpublished Doctorate Thesis).University of Firat, Elazığ

Yıldırım, A., \& Şimşek, H. (2013). Qualitative research methods in the social sciences. Ankara: Seçkin Publication.

Y1lmaz, E. (2006). To Investigate the effect of school managers' ethical leadership levels on the organizational trust level and to test whether the organizational trust level in schools differentiate with respect to some variables or not. (Unpublished Master's Thesis). University of Selçuk, Konya, Türkiye.

Zahra, S. A. (1985). Background and work experience correlates of the ethics and effect of organizational politics. Journal of Business Ethics, 4(5), 419-423. https://doi.org/10.1007/BF02388597

\section{Copyrights}

Copyright for this article is retained by the author(s), with first publication rights granted to the journal.

This is an open-access article distributed under the terms and conditions of the Creative Commons Attribution license which permits unrestricted use, distribution, and reproduction in any medium, provided the original work is properly cited. 